\title{
Knock-In Mice Lacking the PDZ-Ligand Motif of mGluR7a Show Impaired PKC-Dependent Autoinhibition of Glutamate Release, Spatial Working Memory Deficits, and Increased Susceptibility to Pentylenetetrazol
}

\author{
Chuan-Sheng Zhang, ${ }^{1 \star}$ Federica Bertaso, ${ }^{2 \star}$ Volker Eulenburg, ${ }^{1 \star}$ Mireille Lerner-Natoli, ${ }^{2}$ Greta Ann Herin, ${ }^{1}$ \\ Liane Bauer, ${ }^{1}$ Joel Bockaert, ${ }^{2}$ Laurent Fagni, ${ }^{2}$ Heinrich Betz, ${ }^{1}$ and Astrid Scheschonka ${ }^{1}$ \\ ${ }^{1}$ Department of Neurochemistry, Max Planck Institute for Brain Research, 60528 Frankfurt am Main, Germany, and ${ }^{2}$ Institut de Génomique Fouctionelle, \\ Centre National de la Recherche Scientifique, Unité Mixte de Recherche 5203, INSERM U-661, University of Montpellier I and II, 34094 Montpellier Cedex \\ 05, France
}

\begin{abstract}
The metabotropic glutamate receptor 7 (mGluR7) is widely expressed throughout the brain and primarily localized at presynaptic active zones, where it is thought to regulate neurotransmitter release. Protein interacting with C kinase 1 (PICK1), a postsynaptic density protein-95/disc-large tumor suppressor protein/zonula occludens-1 (PDZ)-domain protein, binds to the three C-terminal amino acids (-LVI) of the predominant mGluR7 splice variant, mGluR7a, and has been implicated in the synaptic clustering of this receptor. Here, we generated knock-in mice in which the C-terminal LVI coding sequence of exon 10 of the mGluR7 gene was replaced by three alanine codons (-AAA). Immunoprecipitation showed that the PICK1-mGluR7a interaction is disrupted in $m G l u R 7 a^{A A A / A A A}$ mice. However, the synaptic localization of mGluR7a was not altered in cultured hippocampal neurons and brain sections prepared from the knock-in animals. In cerebellar granule cell cultures, the group III mGluR agonist L-AP-4 decreased the frequency of spontaneous excitatory currents in neurons derived from wild-type but not $m G l u R 7 a^{A A A / A A A}$ mice, consistent with the interaction between mGluR7a and PICK1 being required for protein kinase $\mathrm{C}$-mediated inhibition of glutamate release. At the behavioral level, the $m G l u R 7 a^{A A A / A A A}$ mice showed no deficits in motor coordination, pain sensitivity, and anxiety but exhibited significant defects in hippocampus-dependent spatial working memory. In addition, they displayed a high susceptibility to the convulsant drug pentylenetetrazole. Together, these results indicate that PICK1 binding to the C-terminal region of mGluR7a is crucial for agonist-triggered presynaptic signaling in vivo.
\end{abstract}

Key words: metabotropic glutamate receptor 7; PICK1; synaptic clustering; PKC signaling; working memory; pentylenetetrazol

\section{Introduction}

G-protein-coupled metabotropic glutamate receptors (mGluRs) are modulators of fast synaptic transmission mediated by ionotropic glutamate receptors. The mGluR7 subtype is the most prominent member of the group III mGluR subfamily found on presynaptic terminals in different brain regions (Bradley et al.,

\footnotetext{
Received Feb. 12, 2008; revised July 2, 2008; accepted July 12, 2008.

This work was supported by the Max-Planck-Gesellschaft, European Community Grant QLG3-CT-2001-00929, Fonds der Chemischen Industrie, Cluster of Excellence "Macromolecular Complexes" at J. W. Goethe-University Frankfurt (DFG Project EXC 115), and Agence Nationale de la Recherche-06-NEUR0-035-01. We thank Dr. Andreas Karschin (University of Wuerzburg, Germany) for the GIRK (Kir3.1/3.2) expression construct, Dr. Richard Huganir (Johns Hopkins University, Baltimore, MD) for the ample supply of PICK1 antibody, Dr. Ulrike Müller (University of Heidelberg, Germany) for 129/0LA ES cells and expert advice, and Walter Hofer (Max Planck Institute for Brain Research) for electron microscopy. The $m G l u R 7^{-/-}$mice were generously provided by Dr. Hermann van der Putten (Novartis Pharma, Basel, Switzerland). The expert technical and secretarial assistance of Nicole Fürst and Maren Baier is gratefully acknowledged.

${ }^{*}$ C.-S.Z., F.B., and V.E. contributed equally to this work.

Correspondence should be addressed to Dr. Heinrich Betz, Department of Neurochemistry, Max Planck Institute for Brain Research, Deutschordenstrasse 46, 60528 Frankfurt am Main, Germany. E-mail: neurochemie@mpih-frankfurt.mpg.de.

D0I:10.1523/JNEUROSCI.0628-08.2008

Copyright $\odot 2008$ Society for Neuroscience $\quad$ 0270-6474/08/288604-11\$15.00/0
}

1996; Kinoshita et al., 1998). It provides neurons with a negative feedback mechanism which, by inhibiting voltage-dependent $\mathrm{Ca}^{2+}$ channels, reduces glutamate release (Bushell et al., 1996; Perroy et al., 2000; Millan et al., 2002). Because of its low affinity for glutamate, mGluR7 has been proposed to only be activated under conditions of sustained synaptic activity (Okamoto et al., 1994).

Progress in elucidating how mGluR7 controls neurotransmission has been hindered by the lack of specific ligands. The presently available agonists activate all group III mGluRs (Yang, 2005) and display anticonvulsant effects both in vitro and in vivo (Gasparini et al., 1999; Folbergrová et al., 2003). mGluR7deficient mice are hypersensitive to proconvulsive agents, such as pentylenetetrazol (PTZ) and bicuculline, and develop epileptic seizures under particular conditions (Sansig et al., 2001). In addition, $m G l u R 7^{-\prime-}$ mice display altered anxiety responses (Cryan et al., 2003; Mitsukawa et al., 2006), spatial working memory deficits, and a delayed extinction of conditioned fear (Hölscher et al., 2004; Callaerts-Vegh et al., 2006). Based on these findings, mGluR7 is considered a promising target for the development of wide-spectrum therapeutic drugs (Dev, 2004). 
The importance of mGluR7 in fine-tuning synaptic transmission is highlighted by the complexity of its signaling pathways (El Far and Betz, 2002). The intracellular C-terminal domain of the macrophage major splice variant mGluR7a interacts with several cytosolic proteins, including $\mathrm{Ca}^{2+}$-calmodulin (O'Connor et al., 1999), the protein kinase C (PKC) substrate MacMARCKS (macrophaged myristoylated alanine-rich $\mathrm{C}$ kinase substrate-related protein) (Bertaso et al., 2006), G-protein $\beta \gamma$ subunits, and the protein interacting with C kinase 1 (PICK1) (Dev et al., 2000; El Far et al., 2000), whereas the other known isoform, mGluR7b, binds filamin A, protein phosphatase 1C, syntenin, and PICK1 (Enz and Croci, 2003). PICK1 belongs to a large family of postsynaptic density protein-95/disc-large tumor suppressor protein/zonula occludens-1 (PDZ)-domain proteins known to be essential for diverse receptor signaling and targeting mechanisms (Dev, 2004). The three C-terminal amino acids of mGluR7a (-LVI) constitute a PDZ-ligand motif that is crucial for PICK1 binding (Dev et al., 2000; El Far et al., 2000). The interaction with PICK1 has been described to be required for both presynaptic clustering of mGluR7a in cultured hippocampal neurons (Boudin et al., 2000) and mGluR7a-mediated, PKCdependent inhibition of $\mathrm{P} / \mathrm{Q}$-type calcium channels in isolated cerebellar granule cells (Perroy et al., 2002). To characterize the functional roles of the mGluR7a-PICK1 interaction in vivo, we generated knock-in mice in which the C-terminal PDZ-ligand motif (-LVI) of mGluR7a is replaced by alanines (-AAA). Here, we show that the PDZ-ligand motif of mGluR7a is essential for PKC-dependent regulation of synaptic transmission, and that its substitution results in a spatial working memory deficit and higher susceptibility to the convulsant PTZ.

\section{Materials and Methods}

Oocyte electrophysiology. Isolation, defolliculation, and storage of Xenopus laevis oocytes were performed as described previously (Laube et al., 1997). Two-electrode patch-clamp recordings from oocytes expressing G-protein-coupled inwardly rectifying potassium channels (GIRKs) and mGluR7a, or mGluR7a ${ }^{\text {AAA }}$, proteins were conducted as described previously (Laube et al., 1995). GIRK (Kir3.1/3.2) was a gift from Dr. Andreas Karschin (University of Wuerzburg, Wuerzburg, Germany) (O'Connor et al., 1999). Mutant mGluR7a ${ }^{\mathrm{AAA}}$ was generated by PCR mutagenesis from the wild-type (wt) mGluR7a cDNA, and both were subcloned into pSGEM using EcoRI and SalI sites to obtain Xenopus oocyte expression constructs. Constructs were linearized with NotI and translated in vitro using the mMessage mMachine kit (Ambion). RNAs were stored in aliquots at $-20^{\circ} \mathrm{C}$. L-AP- 4 was obtained from Calbiochem and L-glutamate from Sigma Chemicals.

For recordings, data were acquired with a GeneClamp 500b amplifier, Digidata 1320 signal conditioner, and pClamp 9 software (Molecular Devices). The volume of the perfusion chamber was $\sim 15 \mu$ l, and this volume was exchanged at a rate of $10 \mathrm{ml} / \mathrm{min}$ with ND96 (Dascal et al., 1985) and solutions containing high $\mathrm{K}^{+}$. Agonist application was performed manually.

Generation and breeding of mutant mice. A genomic bacterial artificial chromosome clone containing the mGluR7 gene locus (RP23-391F16) was obtained from BACPAC Resources Centre (Children's Hospital, Oakland Research Institute, Oakland, CA). Genomic DNA fragments harboring exon 10 of the mGluR7 gene were subcloned in pBluescript (Stratagene). The targeting vector comprised a $5.2 \mathrm{~kb}$ long arm and a 1.5 $\mathrm{kb}$ short arm, with a PGK (phosphoglycerate kinase)-neomycin resistance $\left(\mathrm{Neo}^{\mathrm{r}}\right)$ selection cassette being flanked by two LoxP sites and the herpes simplex thymidine kinase gene. A triple alanine mutation that replaced the last three codons (-LVI) in exon 10 was introduced by sitedirected PCR mutagenesis. The targeting vector, based on a modified version of pEasyflox (kindly donated by Dr. K. Rajewski, University of Cologne, Cologne, Germany), was linearized and electroporated into mouse embryonic stem (ES) cells (129/OLA). Positive clones were iden- tified by PCR and confirmed by Southern blot analysis using external and internal probes. Two targeted ES clones were expanded for Cre-mediated deletion in ES cells by transient transfection with a Cre recombinase expression vector as described previously (Hirzel et al., 2006). Neo excision was confirmed by PCR and Southern blotting. Positive ES cell clones were injected into $\mathrm{C} 57 \mathrm{BL} / 6 \mathrm{~J}$ blastocysts to produce germline transmitting chimeric mice, which then were mated with C57BL/6J mice. The resulting heterozygous offspring were intercrossed to generate wt $(+/+)$, heterozygous $m G l u R 7 a^{+/ A A A}$, and homozygous $m G l u R 7 a^{A A A / A A A}$ mice. For behavioral analysis, F1 heterozygous mice were backcrossed with C57BL/6J mice for six generations.

mGluR7 knock-out mice, kindly provided by Dr. Hermann van der Putten (Novartis Pharma, Basel, Switzerland), were maintained as heterozygous line and genotyped as described (Sansig et al., 2001).

RNA isolation and Northern blot analysis. TRIZOL reagent (Invitrogen) was used for the isolation of total RNA from brains of wt and $m G l u R 7 a^{A A A / A A A}$ mice according to the manufacturer's instructions. For Northern blot analysis, $20 \mu \mathrm{g}$ of total brain RNA was separated on a $1 \%$ agarose gel, blotted, and probed with a ${ }^{32} \mathrm{P}$-labeled $199 \mathrm{bp}$ PCR fragment encoding the cytosolic tail of mGluR7a as a hybridization probe. As a loading control, the membrane was reprobed with a 714 bp PCR fragment of the mouse $\beta$-actin cDNA.

Preparation of crude membrane fractions and Western blotting. Mouse brains were dissected, frozen in liquid nitrogen, and homogenized in ice-cold lysis buffer (50 mM HEPES-Cl, pH 7.4, 10 mM EDTA, and $50 \mathrm{~mm}$ $\mathrm{NaCl}$ containing Complete Protease Inhibitor Cocktail; Roche Diagnostics). The homogenate was centrifuged at $500 \times g$ for $15 \mathrm{~min}$ at $4^{\circ} \mathrm{C}$, the pellet discarded, and the supernatant recentrifuged at $20.000 \times g$ for 30 min at $4^{\circ} \mathrm{C}$. The resulting pellet (P2 fraction) was suspended in homogenization buffer, and protein concentrations were determined by the Bradford Protein Assay (Bio-Rad). Crude membrane protein $(50 \mu \mathrm{g})$ was loaded per lane, separated by $8 \%$ SDS-PAGE, and transferred to nitrocellulose membranes (Whatman). The membranes were probed with rabbit anti-mGluR7 (1:4000; Upstate), rabbit anti-mGluR4 (1:1000; Upstate), or rabbit anti-PICK1 (1:1000; generous gift from Dr. Richard Huganir, John Hopkins University, School of Medicine, Baltimore, MD), followed by peroxidase-labeled anti-rabbit IgG (Dianova). To control for protein loading, the membranes were stripped and reprobed with a mouse monoclonal $\beta$-tubulin antibody (1:1000; Millipore). Band intensities were quantified by NIH Image.

Coimmunoprecipitation. Mouse brains dissected from wt and $m$ GluR $7 a^{A A A / A A A}$ mice were homogenized in coimmunoprecipitation buffer [(in mM) 50 Tris-Cl, pH 7.5, 15 EGTA, $100 \mathrm{NaCl}, 1$ dithiothreitol including Complete Protease Inhibitor Cocktail]. The homogenates were centrifuged at $800 \times g$ for $10 \mathrm{~min}$, the supernatant was collected and centrifuged at $20,000 \times g$ for $1 \mathrm{~h}$, and the pellet resuspended in the same buffer containing $1 \%(\mathrm{v} / \mathrm{v})$ Triton X-100. After overnight solubilization at $4^{\circ} \mathrm{C}$ on a shaker, insoluble material was removed by centrifugation, and the supernatants were stored at $-80^{\circ} \mathrm{C}$. Before coimmunoprecipitation, detergent extracts prepared from wt mice were diluted to compensate for the reduced mGluR7a protein level found in mutant mice (see Fig. 3), and then both wt and knock-in samples were preadsorbed on protein G-Sepharose beads (GE Healthcare) for $1 \mathrm{~h}$ at $4^{\circ} \mathrm{C}$. Proteins were immunoprecipitated by overnight incubation at $4^{\circ} \mathrm{C}$ with $4 \mu \mathrm{g}$ antiPICK1 antibody (N18; Santa Cruz Biotechnology), followed by adsorption to protein G-Sepharose beads. In control experiments, nonspecific goat IgGs were used instead of the PICK1 antibody. After repeated washing of the beads, bound proteins were eluted with SDS sample buffer and separated by $10 \%$ SDS-PAGE, followed by Western blotting with mGluR7a antibody (Upstate).

Primary culture of hippocampal neurons and immunocytochemistry. Hippocampal primary cultures were prepared and maintained as described previously (Fuhrmann et al., 2002). At days 21-28 in vitro, cells were fixed for immunocytochemistry with $4 \%$ (w/v) paraformaldehyde in PBS for $10 \mathrm{~min}$ and then washed four times with PBS for $10 \mathrm{~min}$, each. After permeabilizing with $0.1 \%(\mathrm{w} / \mathrm{v})$ Triton X-100 and blocking with $5 \%(\mathrm{v} / \mathrm{v})$ goat serum in PBS, the cells were incubated with rabbit antimGluR7a (1:200; Upstate) and/or mouse anti-synapsin I (1:400; Synaptic Systems), followed by Alexa Fluor 488- and 546-conjugated secondary 
antibodies (Invitrogen). Images were captured with a Leica TCS-SP confocal laser-scanning microscope equipped with $40 \times$ and $63 \times$ objectives.

Histology and immunohistochemistry. Two-month-old mice were anaesthetized with pentobarbital sodium $(80 \mathrm{mg} / \mathrm{kg}$, i.p.) and perfused with $4 \%(\mathrm{w} / \mathrm{v})$ paraformaldehyde. Then, the brains were removed, postfixed in $4 \%(\mathrm{w} / \mathrm{v})$ paraformaldehyde, and transferred to $30 \%(\mathrm{w} / \mathrm{v})$ sucrose for cryoprotection. Sagittal sections $(20 \mu \mathrm{m})$ were cut and stored at $-20^{\circ} \mathrm{C}$ until further processing. Sections were stained with $0.5 \%(\mathrm{w} / \mathrm{v})$ cresyl violet to assess histological changes in $m G l u R 7 a^{A A A / A A A}$ mouse brains (three animals per genotype). To immunohistochemically detect mGluR7a protein expression and localization, an antibody directed against the $\mathrm{C}$ terminus of mGluR7a was used (Upstate). Briefly, brain sections were permeabilized for $30 \mathrm{~min}$ with $4 \%$ (v/v) goat serum $/ 0.3 \%$ $(\mathrm{w} / \mathrm{v})$ Triton X-100 in PBS and blocked with $1 \%(\mathrm{w} / \mathrm{v})$ bovine serum albumin (BSA) and 10\% (v/v) goat serum in PBS, then incubated with mGluR7a antibody (1:200) in blocking buffer overnight at $4^{\circ} \mathrm{C}$, washed in PBS, and finally incubated with goat anti-rabbit secondary antibodies coupled to Alexa 488 (1:500; Invitrogen). Images were collected using a Zeiss Axio Imager Z1 fluorescence microscope.

Preembedding immunoelectron microscopy. Two-month-old mice were deeply anaesthetized by inhalation of isoflurane and killed by cervical dislocation. Hippocampi and cerebellum were dissected and immediately immersion fixed in $4 \%(\mathrm{w} / \mathrm{v})$ paraformaldehyde, $0.05 \%(\mathrm{v} / \mathrm{v})$ glutaraldehyde, and $0.75 \%(\mathrm{w} / \mathrm{v})$ picric acid in sodium phosphate buffer $(0.1$ $\mathrm{M}, \mathrm{pH}$ 7.6) for $2 \mathrm{~h}$. After washing with PBS, the hippocampus and cerebellar tissues were embedded in agar and sectioned on a vibratome at 60 $\mu \mathrm{m}$ thickness. Sections were taken from the hippocampus and the cerebellar folia III-V. After cryoprotection in 10, 20, and 30\% (w/v) sucrose for $1 \mathrm{~h}$ each, the sections were frozen and thawed twice in liquid nitrogen to increase penetration of immunoreagents and blocked for $2 \mathrm{~h}$ in $10 \%$ $(\mathrm{v} / \mathrm{v})$ normal goat serum, $1 \%(\mathrm{w} / \mathrm{v})$ BSA in PBS. This was followed by incubation with mGluR7a antibody [1:200, 1:400, and 1:1000 dilution in $2 \%(\mathrm{v} / \mathrm{v})$ goat serum, $1 \%(\mathrm{w} / \mathrm{v})$ BSA, $0.05 \%(\mathrm{w} / \mathrm{v})$ sodium azide in PBS] for $3 \mathrm{~d}$ at $4^{\circ} \mathrm{C}$. After washing with PBS, the sections were incubated for $2 \mathrm{~h}$ with biotinylated goat anti-rabbit IgG (1:100; Vector Laboratories), rinsed with $\mathrm{PBS}$, and transferred to a solution containing avidinbiotinylated peroxidase complex (diluted 1:100 in Tris-buffered saline; Vector Laboratories) for $1 \mathrm{~h}$ at room temperature. After washing twice with PBS and twice with $0.05 \mathrm{M}$ Tris- $\mathrm{HCl}, \mathrm{pH} 7.4$, bound peroxidase was visualized by incubation with $0.05 \%(\mathrm{v} / \mathrm{v}) 3,3$-diaminobenzidine, and $0.01 \% \mathrm{H}_{2} \mathrm{O}_{2}$ for $8 \mathrm{~min}$. The staining reaction was stopped by washing the sections sequentially in Tris- $\mathrm{HCl}, \mathrm{pH} \mathrm{7.4,} \mathrm{and} \mathrm{PBS.} \mathrm{The} \mathrm{sections} \mathrm{were}$ then postfixed in $2.5 \%(\mathrm{v} / \mathrm{v})$ glutaraldehyde in cacodylate buffer, $\mathrm{pH} 7.4$, for $2 \mathrm{~h}$ at $4^{\circ} \mathrm{C}$ and washed with double-distilled water, followed by silver intensification and $0.05 \%(\mathrm{w} / \mathrm{v})$ gold chloride treatment (SassoèPognetto et al., 1994). After washing, the sections were treated with $0.5 \%$ $(\mathrm{w} / \mathrm{v}) \mathrm{OsO}_{4}$ in cacodylate buffer for $30 \mathrm{~min}$, washed in PBS, and contrasted in $2 \%(\mathrm{w} / \mathrm{v})$ uranyl-acetate for $2 \mathrm{~h}$. After dehydration in ethanol, they were embedded in Epon resin (Fluka). Serial ultrathin sections were stained with uranyl-acetate and lead citrate. Electron micrographs were obtained with a Zeiss EM10C transmission electron microscope by examining the CA3 region of the hippocampus and the granule cell layer of the cerebellum. Two brains of each genotype were used for sample preparation, and three blocks per mouse were cut for immunoelectron microscopy.

Electrophysiology in cerebellar granule cell cultures. Primary cultures of cerebellar granule cell neurons were prepared as described (Bertaso et al., 2006). Briefly, 8-d-old mice were decapitated, and the cerebella dissected and mechanically dissociated in DMEM:F12 medium (1:1; Invitrogen) supplemented with (in mM) 30 glucose, 2 glutamine, 13 sodium bicarbonate, 5 HEPES, pH 7.4, 10\% semisynthetic calf serum (Biowhittaker), antibiotics, and $25 \mathrm{KCl}$. Cells were then plated at a density of $3-5 \times 10^{5}$ cells/dish on $35 \mathrm{~mm}$ dishes coated with poly-L-ornithine. Forty-eight hours before electrophysiological recording, $50 \%$ of the medium was replaced by culture medium containing $5 \mathrm{~mm} \mathrm{KCl}$.

Cultured cerebellar granule neurons were recorded at 9-10 d in vitro using the whole-cell patch-clamp configuration at room temperature as described previously (Perroy et al., 2002). L-AP-4 was applied using a fast gravity perfusion system that allowed complete exchange of the media in
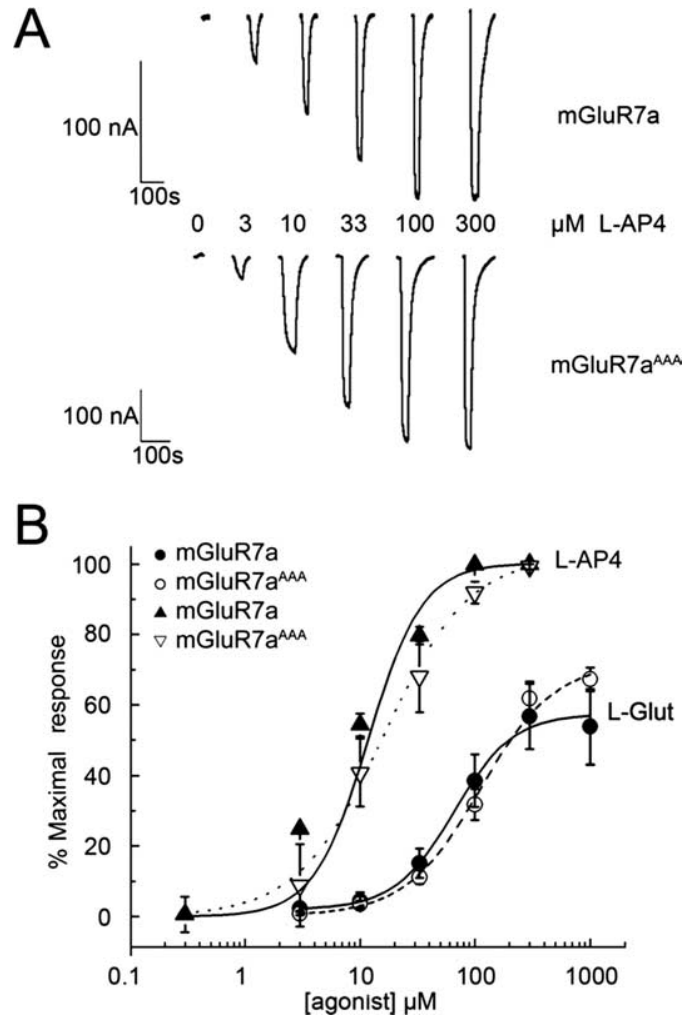

Figure 1. Substitution of the mGluR7a PDZ-ligand motif does not affect G-protein coupling. $A$, Comparison of L-AP-4-dependent currents in Xenopus oocytes coinjected with Kir3.1/3.2 and mGluR7a (top) or mGluR7a $a^{A A A / A A A}$ (bottom), cRNAs. Increasing L-AP-4 concentrations elicited similar responses at both wt and mutant receptors. B, Dose-response curves for L-AP-4 (triangles) and L-glutamate (circles) responses of Xenopus oocytes coexpressing Kir3.1/3.2 and mGluR7a (solid symbols, solid lines) or mGluR7a aAA (hollow symbols, dashed lines), respectively. Glutamate responses were normalized to saturating L-AP-4 responses in the same 00cyte. Note that L-glutamate acts as a partial agonist at mGluR7a in comparison to L-AP-4 in this expression system. Data represent mean \pm SEM from four to five oocytes.

$<50$ ms. Neurons were exposed to the PKC inhibitor 3-[1-(3-dimethylamino)propyl]-1 $H$-indol-3-yl]-4-( $1 H$-indol-3-yl)- $1 H$-pyrrolyl-2,5-dione (GF109203X; $10 \mu \mathrm{M}$; Research Biomedicals) for at least 45 min before recording. Data were analyzed using the pClamp version 9 software (Molecular Devices). Once a minimal sample of at least 120 events had been collected, the average frequency and amplitude of these events were evaluated.

Surgery, microinjections, and EEG recordings. These procedures were approved by the French Ministry for Agriculture (authorization no. 34178). Wild-type or $m G l u R 7 a^{A A A / A A A}$ mice were anesthetized with 2 $\mathrm{ml} / \mathrm{kg}$ of a saline solution containing $40 \%(\mathrm{v} / \mathrm{v})$ ketamine (Imalgene 500 ) and $20 \%(\mathrm{v} / \mathrm{v})$ xylazine (Rompun $2 \%$ ) and placed in a stereotaxic frame using the David Kopf mouse adaptor. Five monopolar electrodes made of silver wires (diameter, $125 \mu \mathrm{m}$; Phymep) soldered on a male microconnector (Mateleco) were extradurally inserted in the skull, two on each parietal bone and one on the frontal bone as ground reference. The microconnector was then fixed with dental acrylic cement. After surgery, animals were individually housed and maintained in a $12 \mathrm{~h} \mathrm{light/dark}$ cycle with food and water ad libitum for 1 week of recovery.

For recordings, animals were put into individual Plexiglas boxes, and their microconnectors were plugged to an EEG preamplifier box. The electrical activity recorded by extradural electrodes was filtered and recorded by a computer equipped with Dasylab software. A $1 \mathrm{~h}$ period of baseline recording before PTZ (Sigma Chemicals) injection allowed detection of EEG abnormalities independent of experimental manipulations. EEG recordings were performed together with monitoring animal behavior. The symptoms developing after injection were classified into different phases as described by Weiergräber et al. (2006). Phase 1 corre- 
A

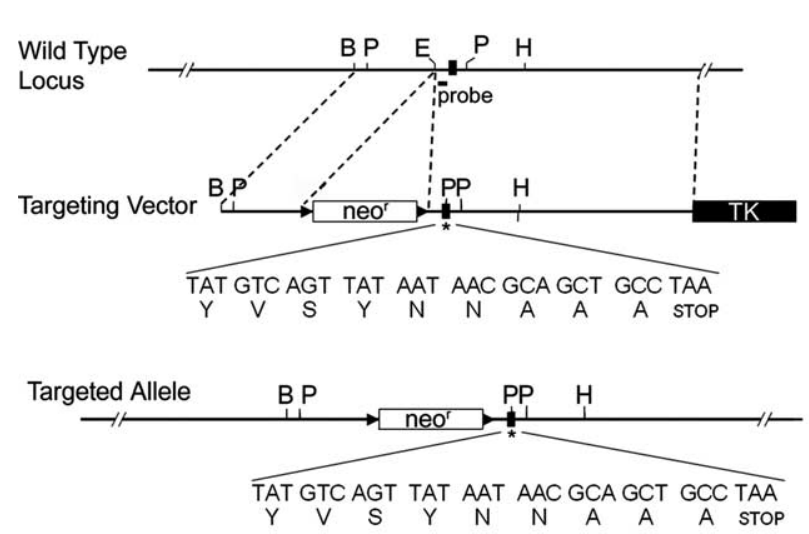

Targeted Allele after Cre Excision

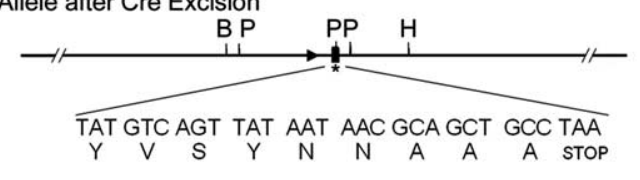

$1 \mathrm{~kb}$
B
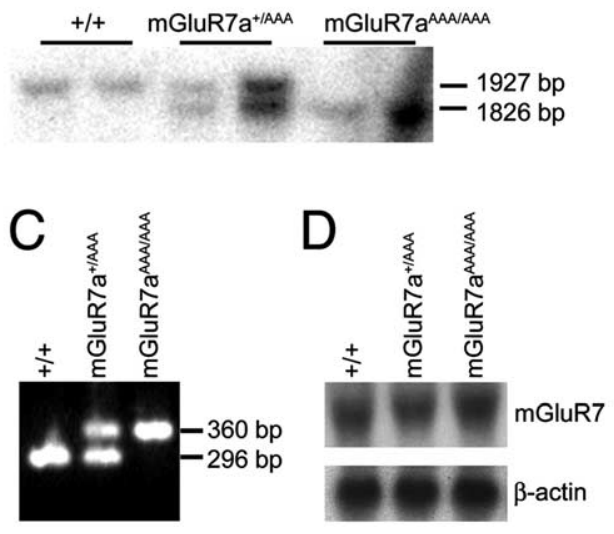

$\mathrm{E}$

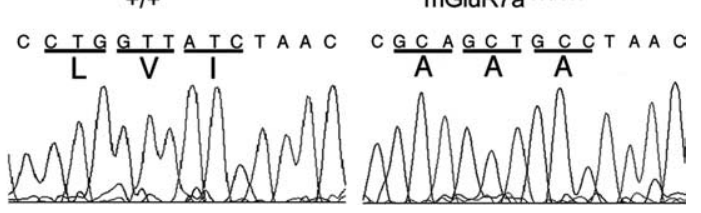

Figure 2. Generation of $m G / u R 7 a^{A A A / A A A}$ mice. $A$, Gene targeting strategy. Exon 10 of the mGluR7 locus was selected for homologous recombination. The targeting vector contained exon 10 (striped box) with a substitution (asterisk) that replaced the coding sequence of the PDZ-ligand motif (-LVI) of mGluR7a by three alanine codons (resulting amino acid sequence indicated below), $5^{\prime}$ and $3^{\prime}$ homology regions placed upstream and downstream of the mutated exon 10, and $\mathrm{Ne}^{r}{ }^{r}$ and thymidine kinase (TK) selection cassettes. The Neo ${ }^{r}$ cassette was flanked by two LoxP sites (triangles). After homologous recombination in $\mathrm{ES}$ cells, the remaining $\mathrm{Ne}^{r}{ }^{\mathrm{r}}$ cassette was removed from the targeted allele by transfection with a Cre expression vector. Relevant restriction sites: $\mathrm{E}$, EcoRl; B, BamHI; P, Pvull; H, Hindlll. B, Southern blot analysis of Pvull digested mouse genomic DNA indicated proper homologous recombination. The Southern probe used (indicated in $A$ ) hybridized to expected $1927 \mathrm{bp}$ wt and $1836 \mathrm{bp}$ mutant bands; two examples are shown per genotype. C, PCR genotyping of offspring from heterozygous breedings using primers flanking the remaining LoxP site. $\boldsymbol{D}$, Northern-blot analysis revealed similar mGluR7 transcript levels in wt, heterozygous, and homozygous littermates. $\boldsymbol{E}$, Sequencing of RT-PCR products from $+/+$ and $m G /$ luR7 $a^{A A A / A A A}$ mice confirmed correct substitution of the -LVI coding sequence by -AAA codons. Amplicons corresponded to the coding sequence for the intracellular C-terminal region of mGluR7a.

sponds to an "absence-like" nonconvulsive state, with reduced motility and typical prostrated position of the animal. Phase 2 shows partial clonus of head, vibrissae and/or forelimbs. Phase 3 consists of a generalized clonus of the extremities, the tail, and sometimes vocalization; this phase can develop into typical "running fits." Phase 4 corresponds to a generalized tonic-clonic seizure with extension of the four paws; this phase is occasionally followed by death.

Behavioral tests. All behavioral experiments were conducted in accordance with the German law on animal experimentation and approved by Regierungspräsidium Darmstadt (authorization no. V54-19c20/15F126/12). Experimental details and the results of most of the test paradigms used are presented in the supplemental material (available at www.jneurosci.org).

\section{Results}

Binding to the single PDZ domain of PICK1 requires the last three amino acids (-LVI; positions 913-915) of mGluR7a (Dev et al., 2000; El Far et al., 2000). To further characterize the physiological function of this interaction, we choose to generate knock-in mice, in which this PDZ-ligand motif of mGluR7a is replaced by three alanine residues $\left(m G l u R 7 a^{A A A / A A A}\right)$. This substitution has been shown previously to abolish PICK1 binding to the C-terminal region of mGluR7a in vitro (Dev et al., 2000; El Far et al., 2000).

\section{Inactivation of the PDZ-ligand motif does not affect mGluR7a signaling in Xenopus oocytes}

As a first step in creating a mouse model in which the PDZ-ligand motif of mGluR7a is inactivated, we examined whether substitution of the C-terminal -LVI sequence by alanines affects the overall function of mGluR7a. To this end, we investigated the
G-protein $\beta \gamma$-subunit mediated coupling of mGluR7a to GIRK channels (Kir3.1/3.2) (Wischmeyer et al., 1997) in Xenopus laevis oocytes using two-electrode voltage-clamp recording. Current responses to L-glutamate and the group III mGluR selective agonist L-AP-4 were compared between oocytes coinjected with Kir3.1/3.2 cRNA and either mGluR7a or mGluR7a ${ }^{\text {AAA }}$ cRNA. Both oocyte populations produced robust agonist-induced currents, and the concentrations of agonist eliciting a half maximal response $\left(\mathrm{EC}_{50}\right)$ were not significantly different between mGluR7a and mGluR7a ${ }^{\text {AAA }}$ for both L-AP-4 (10.1 $\pm 1.7 \mu \mathrm{M}$ vs $17.3 \pm 6.3 \mu \mathrm{M} ; p=0.090)$ and L-glutamate $(82.4 \pm 10.0 \mu \mathrm{M}$ vs $112.7 \pm 11.3 \mu \mathrm{M} ; p=0.092$ ) (Fig. 1). This is consistent with the triple-alanine substitution of the PDZ-ligand motif not affecting mGluR7a coupling to G-protein activation. Notably, with both the wt and mutant receptors the maximal current elicited by saturating glutamate concentrations was only $53.8 \pm 10.7 \%$ of that produced by L-AP-4 in the same oocytes, indicating that L-glutamate acts only as a partial agonist at mGluR7a.

Generation and characterization of $m G l u R 7 a^{A A A / A A A}$ mice The strategy illustrated in Figure $2 A$ was used for the generation of $m$ GluR $7^{A A A / A A A}$ knock-in mice. A replacement-type targeting vector was constructed that encompassed exon 10, which encodes the last 16 amino acid residues of mGluR7a, and the surrounding genomic sequence of the mGluR7 locus. In this vector, the last three codons of exon 10 were replaced by alanine codons to inactivate the PDZ-ligand motif. The vector was introduced into ES cells by electroporation, and selection for homologous recombination was performed with G418 (geneticin) and FIAU ( 2 '-fluoro-2' deoxy-5-iodo-1- $\beta$-D-arabinofuranosyluracil). Af- 
ter Cre recombinase-mediated excision of the neomycin cassette in ES cells, two successfully targeted independent ES cell clones identified by PCR and Southern blotting (data not shown) were used to produce germline-transmitting chimeric mice. The chimeric mice were then crossed with C57BL/6J female mice to generate F1 heterozygous offspring. No obvious abnormalities in morphology and behavior were found in these F1 animals. F1 heterozygous mice were backcrossed with C57BL/6J mice for six generations. Intercrossing of the heterozygous mice yielded wt $(+/+)$, heterozygous $m G l u R 7 a^{+/ A A A}$, and homozygous $m G l u R 7 a^{A A A / A A A}$ mice in a Mendelian ratio, as revealed by Southern analysis (Fig. $2 B$ ) and PCR genotyping (Fig. 2C). The $m G l u R 7 a^{A A A / A A A}$ homozygous animals were viable and showed no abnormality in size and gross appearance compared with their wt littermates. $\mathrm{Mu}$ tant mice bred normally, groomed well, and showed no detectable differences in body weight (data not shown).

To confirm that the $m G l u R 7$ gene was properly targeted, total brain RNA was prepared from the homozygous $m G l u R 7 a^{A A A / A A A}$ mice, and reverse transcriptase (RT)-PCR was performed to amplify the region of the mGluR7a mRNA encoding the entire intracellular domain of $m$ GluR7 (data not shown). Sequencing of the RT-PCR products showed that the AAA mutation was correctly inserted and expressed in the knock-in animals (Fig. $2 E)$. Northern blot analysis revealed that $m G l u R 7$ mRNA levels were comparable between littermates of different genotype, indicating that there is no downregulation of transcription by this mutation (Fig. 2D).

We next determined whether the amount of mGluR7a protein present in brain differs between wt and $m G l u R 7 a^{A A A / A A A}$ mice. To this end, crude P2 membrane fractions were immunoblotted with an antibody raised against a peptide corresponding to amino acids 899-912 (NSPAAKKKYVSYNN) of human mGluR7a, a sequence that is not present in mGluR7b but fully contained in both the mGluR7 $\mathrm{a}^{\mathrm{WT}}$ and mGluR7 $\mathrm{a}^{\mathrm{AAA}}$ receptors. In agreement with the conservation of the antigenic epitope in both mGluR7a isoforms, Western blot analysis revealed very similar band intensities in cell lysates of human embryonic kidney 293T (HEK 293T) cells transfected with either the mGluR7aWT or mGluR7a AAA cDNA (data not shown). However, quantification of the immunoreactive bands in brain membrane fractions revealed that in $m G l u R 7 a^{A A A / A A A}$ mice, mGluR7a protein levels were significantly reduced by $\sim 35 \%$ compared with wt mice and also modestly reduced $(\sim 15 \%)$ in heterozygous animals (Fig. $3 A, B)$. These reductions were, however, less pronounced than that seen in mice carrying only a single functional mGluR7 allele (decrease of $\sim 50 \%$ ) (supplemental Fig. 1, available at www. jneurosci.org as supplemental material).

In contrast to mGluR7a, PICK1 expression levels did not differ between the $m G l u R 7 a^{A A A / A A A}$ mutants and wt littermates
B

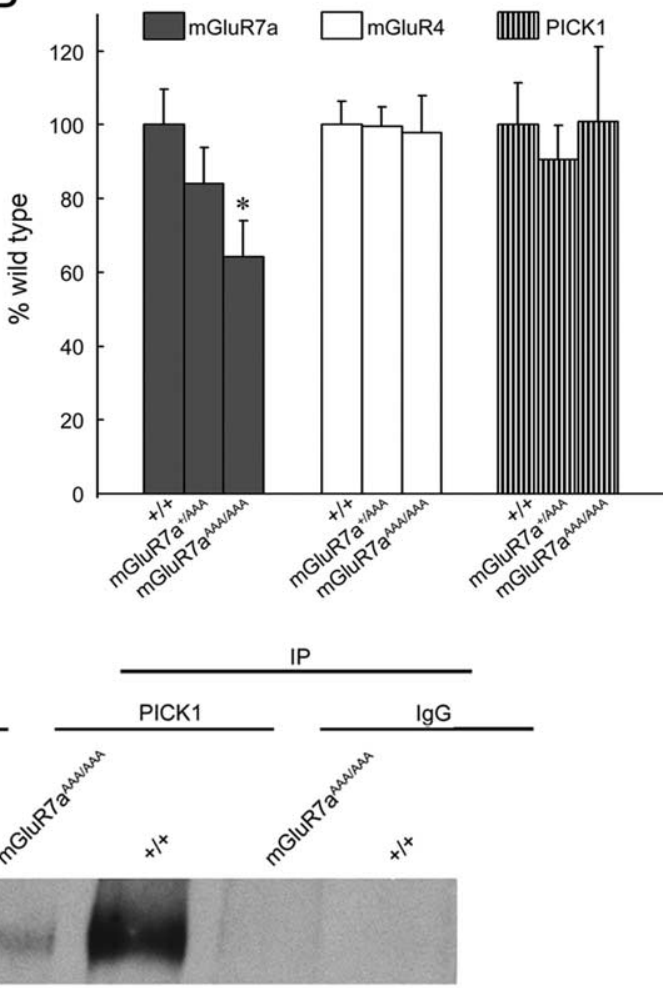

IB: mGluR7a

Figure 3. Reduced mGluR7a expression and impaired PICK1 interaction in $m G / u R 7 a^{A A A / A A A}$ mice. $\boldsymbol{A}$, Western blot analysis of in animals (* $P<0.05$, Student's $t$ test), whereas no difference was found in mGluR4 and PICK1 expression between wt and GluR7a ${ }^{A A A / A A A}$ mice. Data represent mean \pm SEM ( $n=8$ per genotype). C,Coimmunoprecipitation of mGluR7a with PICK1 from were used for immunoprecipitation; the immunoprecipitates and input fractions (left lanes) were analyzed for mGluR7a by Western blotting. Note that little receptor protein was coprecipitated from the $m G / u R 7 a^{A A A / A A A}$ homogenate.

(Fig. $3 A, B$ ). To examine whether other group III mGluRs might compensate for the reduced levels of mGluR7a seen in $m G l u R 7 a^{A A A / A A A}$ mice, we also quantified protein expression of mGluR4. Immunoblotting of the brain membrane fractions did not disclose any differences between mutant and wt mice for this group III receptor (Fig. $3 A, B$ ).

\section{Inactivation of the PDZ-ligand motif impairs mGluR7a- PICK1 interaction in $\boldsymbol{m G l u R 7} \boldsymbol{a}^{A A A / A A A}$ mice}

Deletion or inactivation of the PDZ-ligand formed by the last three amino acids of mGluR7a is known to abolish the PICK1mGluR7a interaction (El Far et al., 2000). To confirm that PICK1 is unable to bind mGluR7a in the knock-in mice, we used a PICK1 antibody for coimmunoprecipitation of mGluR7a from brain extracts. This revealed that mGluR7a could be readily coisolated with PICK1 from wt but not mutant brain extracts, indicating that the triple-alanine substitution impairs mGluR7a binding to PICK1 (Fig. 3C). Quantification of the band intensities disclosed a $83.0 \pm 7.1 \%$ reduction of immunoprecipitated receptor protein with extracts prepared from $m G l u R 7 a^{A A A / A A A}$ compared with $m G l u R 7 a^{+/+}$mice $(n=4$ per genotype; $p<0.01$, Student's $t$ test). Consistent with previous in vitro data (El Far et al., 2000), some residual mGluR7a immunoreactivity consistently was found in the mutant immunoprecipitate (see Discus- 

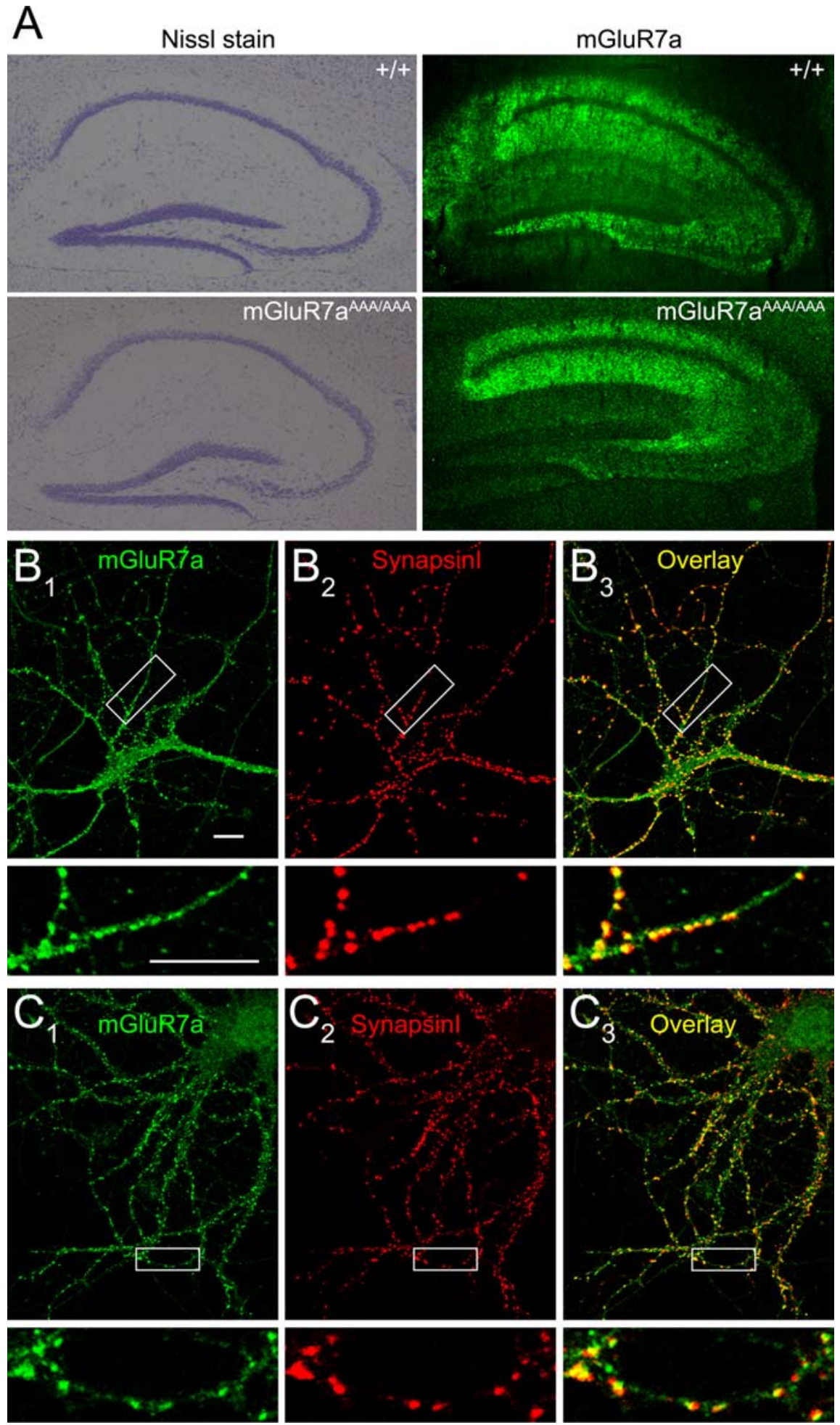

Figure 4. Hippocampal morphology, regional distribution, and synaptic localization of mGluR7a are unaltered in $m G / u R 7 a^{A A A / A A A}$ mice. $\boldsymbol{A}$, Nissl stain (left) and immunohistochemistry with an mGluR7a-specific antibody (right) reveal similar cytoarchitectures and mGluR7a distributions in the hippocampi of wt (top) and $m G / u R 7 a^{A A A / A A A}$ (bottom) mice. $\boldsymbol{B}_{\mathbf{1}}-\boldsymbol{C}_{\mathbf{3}}$, Double immunolabeling of mGluR7a and synapsin I in cultured wt $\left(\boldsymbol{B}_{\mathbf{1}}-\boldsymbol{B}_{3}\right)$ and $m G l u R 7 a^{A A A / A A A}\left(\boldsymbol{C}_{\mathbf{1}}-\boldsymbol{C}_{\mathbf{3}}\right)$ hippocampal neurons. Note the extensive colocalization of mGluR7a immunoreactive puncta with synapsin I on both wt and mutant dendrites. White boxes in the top panels correspond to the enlarged areas shown in the bottom panels. Scale bars, $10 \mu \mathrm{m}$.

sion). Together, these results show that the mGluR7a C-terminal coding region of the mGluR7 locus had been properly mutated, and that the mutation introduced interferes with receptor binding to PICK1.
Gross brain morphology and synaptic localization of mGluR7a are unaltered in mutant animals

To verify that the triple alanine mutation did not affect brain development, we examined Nissl-stained sagittal sections of the mouse brain. $m G l u R 7 a^{A A A / A A A}$ mice showed no detectable abnormalities in the cytoarchitecture of the brain regions examined (cortex, hippocampus, cerebellum) compared with wt controls (data not shown); this is illustrated for the hippocampal formation in Figure 4A. Furthermore, immunohistochemistry failed to reveal significant differences in mGluR7a staining patterns between control and mutant sections.

Next, we investigated whether the synaptic localization of mGluR7a in hippocampal neurons (Shigemoto et al., 1996) might be altered in the knock-in mice, because transfection studies with hippocampal cultures had indicated that PICK1 interaction is required for presynaptic mGluR7a clustering (Boudin et al., 2000; Boudin and Craig, 2001). However, in cultures prepared from our mice, mGluR7a-specific immunofluorescent labeling of wt and mutant hippocampal neurons did not differ, and mGluR7a immunoreactive puncta colocalized with the presynaptic marker synapsin I on both wt and mutant dendrites (Fig. $4 B_{1}-C_{3}$ ). Quantification of the number of immunoreactive puncta revealed no difference in mGluR7a cluster density between $m$ GluR7a $a^{\text {AAA/AAA }}$ neurons $(13.8 \pm 0.15$ puncta per $30 \mu \mathrm{m}$ dendrite) and wt cells (15.0 \pm 0.46 puncta per $30 \mu \mathrm{m}$ dendrite; $p>0.5)$. Apparently, the PDZ-ligand motif of mGluR7a is not essential for synaptic localization in vivo.

To further confirm the synaptic localization of the mGluR7 $\mathrm{a}^{\mathrm{AAA}}$ protein at the ultrastructural level, we performed immunoelectron microscopy on the CA3 region of the hippocampus and the granule cell layer of the cerebellum. For sensitive immunodetection, a method combining peroxidase staining with silver intensification and gold toning was used (SassoèPognetto et al., 1994). In agreement with published data (Ohishi et al., 1995; Bradley et al., 1996; Brandstätter et al., 1996; Shigemoto et al., 1996), mGluR7a immunoreactivity was mostly concentrated at the presynaptic active zone of selected synapses (supplemental Fig. 2, available at www. jneurosci.org as supplemental material) in both wt hippocampal and cerebellar sections (Fig. $5 A, C$ ). In addition, immunoperoxidase reaction product was found in the presynaptic compartment and over synaptic vesicles. We attribute this labeling to product diffusion as seen previously 
(Brandstätter et al., 1996), although the existence of an intraterminal pool of mGluR7a transport vesicles cannot be excluded from our data (supplemental Fig. 2, legend, available at www. jneurosci.org as supplemental material). Very similar staining patterns as found with wt specimens were observed over $m$ GluR $7 a^{A A A / A A A}$ nerve terminals located in both the hippocampal CA3 region and the granule cell layer of the cerebellum (Fig. $5 B, D)$. Thus, the clustering of mGluR7a at active zones in vivo does not depend on efficient mGluR7a-PICK1 interaction.

\section{Loss of mGluR7a-mediated presynaptic inhibition in cerebellar granule cells from $\boldsymbol{m G l u R 7 a ^ { A A A / A A A }}$ mice}

To evaluate whether substitution of the PDZ-ligand motif of mGluR7a affects presynaptic inhibition, we first performed recordings from cultured hippocampal neurons. In cells prepared from both wt and $m G l u R 7 a^{A A A / A A A}$ mice. L-AP-4 at concentrations as low as $10 \mu \mathrm{M}$ significantly reduced both the amplitude and frequency of spontaneous EPSCs (sEPSCs) (data not shown). Apparently, high-affinity group III mGluRs different from mGluR7 (i.e., mGluR4/8) can inhibit excitatory transmission in hippocampal neurons. This is consistent with previous data showing functional expression of mGluR4, mGluR7, and mGluR8 in the mouse hippocampus (O'Connor et al., 1999). Because this mGluR heterogeneity precluded further functional studies of mGluR7a in hippocampal preparations, we turned to cultured cerebellar granule cells, in which mGluR7 responses have been characterized in detail (Perroy et al., 2000, 2002).

In wt cerebellar granule cells, up to $100 \mu \mathrm{M} \mathrm{L}-\mathrm{AP}-4$ had no effect on sEPSCs (Fig. 6E, F). At a concentration of $400 \mu \mathrm{M}$, however, this agonist induced a significant decrease in the frequency but not amplitude of sEPSCs, and this effect was strongly antagonized by the PKC inhibitor GF109203X (10 $\mu \mathrm{M})$ (Fig. $6 A, B, E, F)$. These results corroborate previous findings demonstrating an mGluR7-induced inhibition of sEPSCs through mobilization of a PKC-dependent pathway (Perroy et al., 2002). In contrast, cerebellar neurons prepared from $m G l u R 7 a^{A A A / A A A}$ mice displayed basal sEPSC activity with similar amplitude and frequency as wt neurons, but these synaptic events were insensitive to $400 \mu \mathrm{M} \mathrm{L}-\mathrm{AP}-4$ and GF109203X (Fig. 6C,D, G,H). These results show that the $m G l u R 7 a^{A A A / A A A}$ neurons have lost their ability to activate the PKC-dependent pathway that mediates inhibition of sEPSCs.

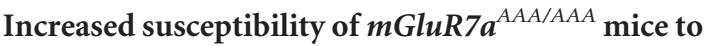 convulsant drugs}

Previous studies have shown that mGluR7 deficient mice are hypersensitive to proconvulsive drugs like PTZ (Sansig et al., 2001). To determine whether inactivation of the mGluR7a PDZligand motif also increases convulsant sensitivity, wt and $m G l u R 7 a^{A A A / A A A}$ mice ( $\geq 9$ weeks old) were injected with PTZ according to Weiergräber et al. (2006). In Figure 7A, examples of EEG traces sampled from wt mice after administration of 70 $\mathrm{mg} / \mathrm{kg}$ PTZ illustrate typical paroxystic activities of the four different epileptic phases defined by these authors. Figure $7 B$ summarizes the phases reached by wt and $m G l u R 7 a^{A A A / A A A}$ mice after injection of different doses of PTZ. At the lowest dose used (40 $\mathrm{mg} / \mathrm{kg}$ ), all wt animals entered phase 1, with typical prostration and EEG spindle activities appearing in the EEG recordings. At the same dose, four of five $m G l u R 7^{A A A / A A A}$ mice showed partial myoclonus typical of phase 2, whereas one animal died as consequence of rapidly developing tonic-clonic seizures. At $50 \mathrm{mg} / \mathrm{kg} \mathrm{PTZ}$, all wt animals entered phase 2, whereas all the $m G l u R 7 a^{A A A / A A A}$ mice showed at least a generalized myoclonus
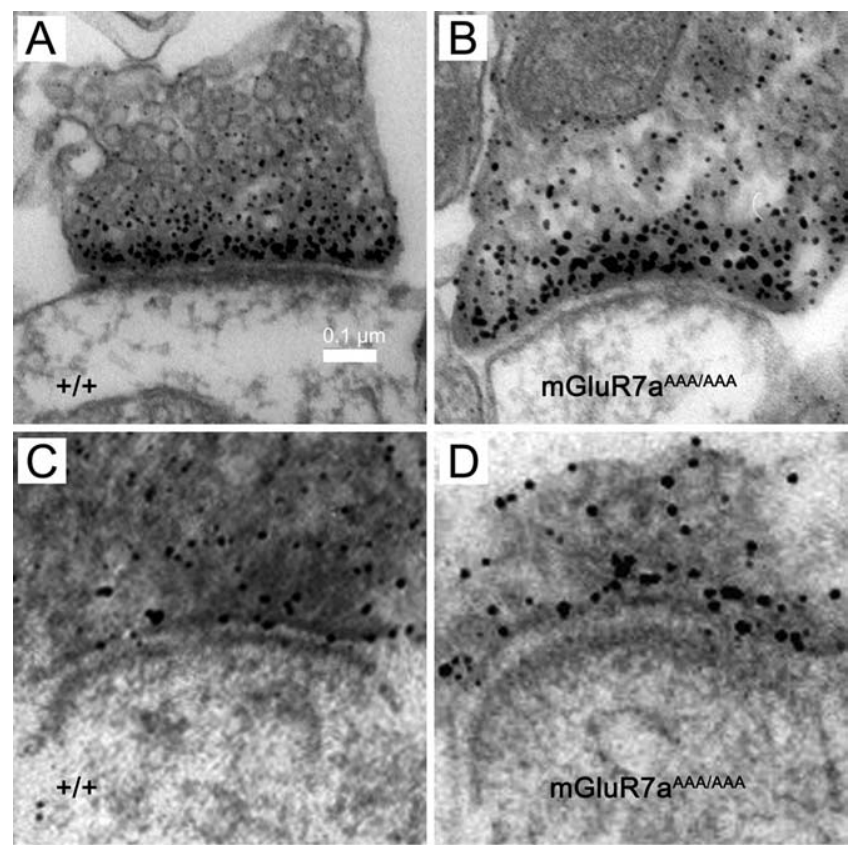

Figure 5. The PDZ-ligand motif of mGluR7a is not essential for synaptic clustering. A-D, Immunoelectron microscopy reveals similar enrichment of $m G l u R 7 a$ in presynaptic terminals of wt $(\boldsymbol{A}, \boldsymbol{C})$ and $m G / u R 7 a^{A A A / A A A}(\boldsymbol{B}, \boldsymbol{D})$ mice. mGluR7a staining is prominent at the active zone and over synaptic vesicles in both the hippocampal $C A 3$ region $(\boldsymbol{A}, \boldsymbol{B})$ and the granule cell layer of the cerebellum $(\boldsymbol{C}, \boldsymbol{D})$ regardless of the genotype.

(phase 3) (Fig. 5C). Four of these animals died in phase 4 seizures. We tested higher doses only on wt animals to ensure that they were indeed able to develop tonic-clonic seizures. Overall, wt mice showed a greater resistance to PTZ than $m G l u R 7 a^{A A A / A A A}$ animals, with $80 \mathrm{mg} / \mathrm{kg}$ being required for wt animals to consistently develop either phase 3 or phase 4 seizures. Moreover, and in contrast to the $m G l u R 7 a^{A A A / A A A}$ mice, all wt animals survived phase 4 and recovered within $30 \mathrm{~min}$. Heterozygous animals $\left(m G l u R 7 a^{A A A /+}\right)$ displayed a phenotype resembling that of wt mice (data not shown). Together, these results indicate that $m G l u R 7 a^{A A A / A A A}$ display an increased susceptibility to PTZ-induced seizures.

\section{Behavioral tests}

To further characterize the $m G l u R 7 a^{A A A / A A A}$ animals, we performed a standard series of behavioral tests that examine motor coordination, pain sensitivity, anxiety, and spatial memory formation in adult mice (open field, tail flick, acoustic startle response, prepulse inhibition, elevated plus maze, Barnes maze). In all of these tests, the knock-in mice were indistinguishable from wt littermates (supplemental text, supplemental Table 1, available at www.jneurosci.org as supplemental material). However, in the eight-arm radial maze, which monitors hippocampusdependent spatial working memory (Bach et al., 1995) and has previously revealed significant differences between wt and $m G l u R 7^{-1-}$ mice (Hölscher et al., 2004), the $m G l u R 7 a^{A A A / A A A}$ mice failed to perform as well as their wt littermates (Fig. 8). During this test, the animals have to remember previously visited arms to efficiently find food rewards; revisits of previously entered arms correspond to a working memory error. In our experiments, mice were trained with one trial per day for $14 \mathrm{~d}$ to optimize food retrieval. Wt mice learned this task and improved their performance over the training $\left(F_{(13,130)}=2.436\right.$; $p<0.01$, one-way repeated-measures ANOVA), whereas the 


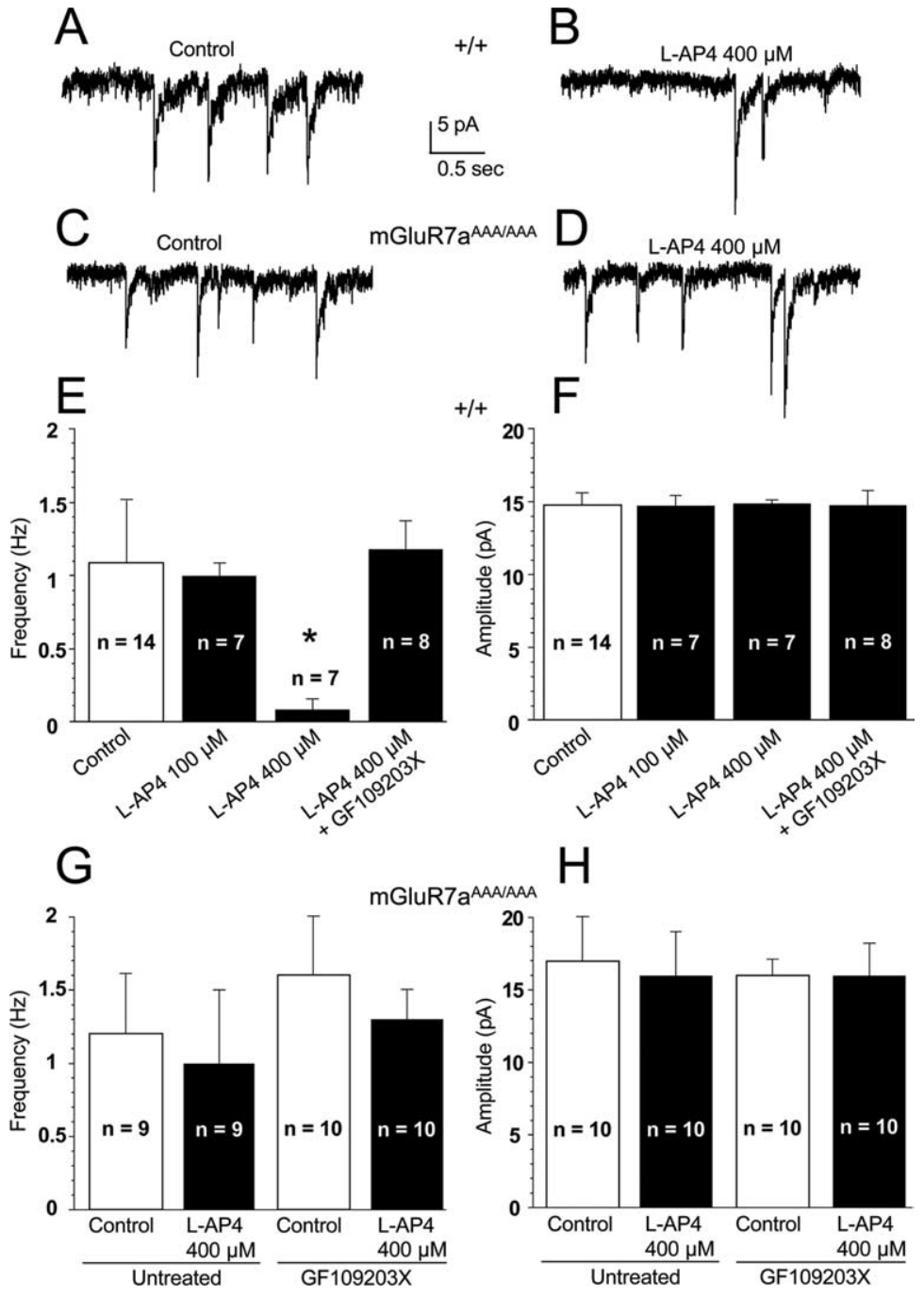

Figure 6. Inhibition of spontaneous EPSCs by the mGluR7 agonist L-AP-4 is impaired in cultured cerebellar granule neurons prepared from $m G / u R 7 a^{A A A / A A A}$ mice. $\boldsymbol{A}-\boldsymbol{D}$, sEPSCs recorded in wt $(\boldsymbol{A}, \boldsymbol{B})$ and $m G / u R 7 a^{A A A / A A A}(\boldsymbol{C}, \boldsymbol{D})$ neurons in the absence $(\boldsymbol{A}, \boldsymbol{C})$ and presence $(\boldsymbol{B}, \boldsymbol{D})$ of $400 \mu \mathrm{m} \mathrm{L}-A P-4$. $\boldsymbol{E}-\boldsymbol{H}$, Quantitative evaluation of the effects of 100 and $400 \mu \mathrm{m}$ L-AP-4 on sEPSC frequency $(\boldsymbol{E}, \boldsymbol{G})$ and amplitude $(\boldsymbol{F}, \boldsymbol{H})$ in the absence and presence of the PKC inhibitor GF109203X (10 $\mu \mathrm{M})$. $\boldsymbol{E}$ and $\boldsymbol{F}$ were obtained in wt, and $\boldsymbol{G}$ and $\boldsymbol{H}$ in $m$ GluR7a $a^{A A A / A A A}$ neurons. Error bars represent the mean \pm SEM of the indicated number of cells. ${ }^{*} p \leq 0.001$, significantly different from control. Note that GF109203X had no effect on the amplitudes and frequencies of sEPSCs in both wt (data not shown) and $m G / u R 7 a^{A A A / A A A}(\mathbf{G}, \boldsymbol{H})$ neurons.

$m$ GluR $7 a^{A A A / A A A}$ mice did not improve significantly $\left(F_{(13,104)}=\right.$ $0.982 ; p=0.474)$. Consequently, the number of revisiting errors (Fig. $8 A$ ) made by the $m G l u R 7 a^{A A A / A A A}$ mice was significantly higher than that made by control mice $\left(F_{(1,13)}=10.14\right.$; $p<0.001$, two-way repeated-measures ANOVA). A highly significant difference was also observed when examining the correct arm choice in the first eight entries between the mutant and wt animals (Fig. $8 B)\left(F_{(1,13)}=13.88, p<0.001\right.$, two-way repeatedmeasures ANOVA). Overall, our results indicate that $m G l u R 7 a^{A A A / A A A}$ mice have an impaired spatial working memory although their exploratory behavior is normal.

\section{Discussion}

This study provides genetic evidence that the PDZ-ligand motif of mGluR7a is important for mGluR7a-mediated inhibition of excitatory neurotransmission, working memory, and resistance to epileptic agents, but not required for localizing the receptor at the presynaptic active zone. Our results are based on the analysis of the $m G l u R 7 a^{A A A / A A A}$ mice in which the C-terminal -LVI codons of exon 10 of the $m G l u R 7$ gene had been substituted by a knock-in approach. By cDNA sequencing, we confirmed that the mutated codons were properly positioned in the mGluR7 gene and transcribed in frame. At the RNA level, no changes in transcription were observed by Northern blotting in the homozygous $m G l u R 7 a^{A A A / A A A}$ mice. However, mGluR7a protein levels were reduced by $35 \%$, whereas expression of another group III mGluR, mGluR4, and of PICK1 was not altered.

Immunoprecipitation with PICK1 antibody revealed that the interaction of PICK1 with the mGluR7a protein was mostly abolished in brain extracts prepared from $m G l u R 7 a^{A A A / A A A}$ mice. However, some mGluR7a immunoreactivity still coprecipitated with PICK1 from the mutant samples. This is in agreement with our previous results where glutathione $S$-transferase-mGluR7a ${ }^{\text {AAA }}$ fusion proteins showed weak residual binding to eGFP-tagged PICK1 expressed in HEK 293 cells (El Far et al., 2000). We attribute this to interaction with mGluR7a residues located N-terminally to the -LVI motif that contribute to PICK1 binding, as described for other PDZ-binding motifs (Hung and Sheng, 2002). Alternatively, PICK1 might bind indirectly to mGluR7a after sumoylation (Tang et al., 2005); this protein modification may occur N-terminally to the -LVI site and mediate interactions with proteins harboring Sumo-binding motifs, as present in PICK1 (Scheschonka et al., 2007).

Substitution of the mGluR7a PDZligand motif had no detectable effects on gross brain morphology or mGluR7a synaptic localization in cultured hippocampal neurons and its ultrastructurally detectable enrichment at active zones in hippocampal and cerebellar nerve terminals. Although we cannot exclude alterations in microcircuitry or in areas that were not examined, all of the presently available results argue against an important role of mGluR7a-PDZ protein interactions in brain development, synapse formation, and synaptic localization of the receptor. Notably, at all levels of microscopic evaluation the distribution and size of mGluR7a immunoreactive clusters were similar in wt and $m G l u R 7 a^{A A A / A A A}$ mice. This differs from findings with cultured hippocampal neurons, in which PICK1 interaction proved to be essential for presynaptic clustering of the recombinant mGluR7a protein (Boudin et al., 2000).

In contrast to the unaltered synaptic anatomy seen in $m G l u R 7 a^{A A A / A A A}$ mice, presynaptic inhibition was severely impaired after PDZ-ligand inactivation. In cerebellar granule cultures, L-AP-4 decreased the frequency but not the amplitude of sEPSCs in wt, but not $m G l u R 7 a^{A A A / A A A}$ neurons. This is consistent with mGluR7a stimulation reducing the number of active glutamatergic release sites without significantly changing the postsynaptic ionotropic glutamate receptor response. The 
mGluR7a-mediated decrease in sEPSC frequency involves PKC because, in wt animals, a PKC-inhibitor, GF109203X, strongly antagonized L-AP-4 inhibition. Apparently, inhibition of release by mGluR7a requires PICK1 binding and mobilization of a PKC $\alpha$-dependent pathway that has been shown to block P/Qtype calcium channels and synaptic transmission in cultured cerebellar granule cells (Perroy et al., 2002). The concentrations of L-AP-4 required to suppress sEPSCs in cerebellar cultures $(400 \mu \mathrm{M})$ are consistent with the absence of functional mGluR4 in cultured cerebellar granule cells. In contrast, in hippocampal neurons, L-AP-4induced effects were seen at considerably lower L-AP-4 concentrations $(10 \mu \mathrm{M})$ because of the presence of high-affinity group-III mGluRs that mask the effects of the mGluR7a mutation. Our results confirm previous studies which disclosed a rather modest inhibition of adenylate cyclase in cerebellar neurons at L-AP-4 concentrations $<100 \mu \mathrm{M}$ (Prézeau et al., 1994). Similarly, low concentrations of L-AP-4 which cause inhibition in the dentate gyrus of the hippocampal formation both in vitro (Cotman et al., 1986) and in vivo (ManahanVaughan and Reymann, 1995), have been reported to be ineffective in cortical neurons (Prézeau et al., 1994), hippocampal CA1 pyramidal cells (Gereau and Conn, 1995) and interneurons (Manahan-Vaughan and Reymann, 1995; Losonczy et al., 2003). Control experiments confirmed that the lack of L-AP-4 effects on cerebellar sEPSC frequency seen in the knock-in animals could not be attributed to direct effects of the AAA substitution on mGluR7a-G-protein coupling. In Xenopus oocytes, the recombinant mGluR7a ${ }^{\mathrm{AAA}}$ protein produced agonist response profiles very similar to those of the wt receptor.

One of the major findings of our study is that $m G l u R 7 a^{A A A / A A A}$ mice display a higher susceptibility to PTZ, a proconvulsive agent, than wt animals. Susceptibility to PTZ has been an important paradigm in studies of group III mGluR-deficient mice; only in mGluR7 knock-out mice has an increased susceptibility to this drug been detected (Sansig et al., 2001). When injected with 40 $\mathrm{mg} / \mathrm{kg}$ PTZ, which is generally subthreshold for inducing seizures in wt animals, none of the wt mice developed neuromotor symptoms, whereas all $m G l u R 7 a^{A A A / A A A}$ mice showed clonic or tonicclonic seizures. A comparable scenario has been found in mGluR7 ${ }^{-1-}$ mice (Sansig et al., 2001), where at the age of 10 weeks or older $\sim 75 \%$ of the animals developed tonic-clonic seizures after administration of $40 \mathrm{mg} / \mathrm{kg}$ PTZ. Thus, inactivation of the PDZ-ligand motif suffices to generate this prominent symptom of the mGluR7-deficiency phenotype.

In behavioral experiments, the $m G l u R 7 a^{A A A / A A A}$ mice did not show any deficits except a significant impairment of spatial working memory in the eight-arm radial maze paradigm. A similar phenotype had been observed in $m G l u R 7^{-1-}$ mice (Hölscher et al., 2004), which further underscores that the triple alanine substitution of the PDZ-ligand severely alters mGluR7a function. We can only speculate in which way the disturbed interaction of mGluR7a and PICK1 materializes during the biochemical process of memory formation. One possibility is that the substitution
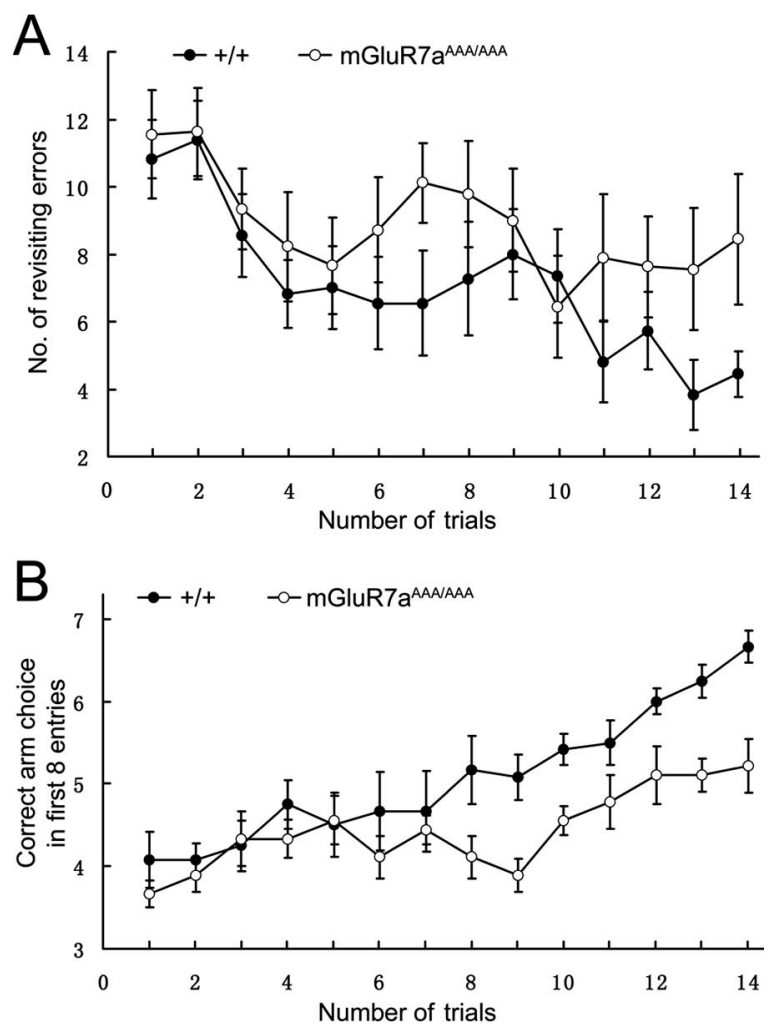

Figure 8. $m$ GluR7 $a^{A A A / A A A}$ mice display working memory deficits in the eight-arm radial maze. $\boldsymbol{A}, \boldsymbol{B}$, Ten-week-old mice were tested in an eight-arm radial maze, and the number of revisiting errors $(\boldsymbol{A})$ and of correct arm choices within the first eight entries $(\boldsymbol{B})$ were determined. Over the training sessions, there was a highly significant decrease of revisiting errors $(\boldsymbol{A})$ and a corresponding increase in the number of correct arm choices $(\boldsymbol{B})$ in wt mice compared with $m$ GluR7 $a^{A A A / A A A}$ animals. Data represent the mean \pm SEM (wt, $n=11 ; m G l u R 7 a^{A A A / A A A}, n=$ $9 ; p<0.001$, two-way repeated-measures ANOVA). 
of the PDZ-ligand motif in mGluR7a not only affects presynaptic inhibition in cerebellar granule cells but also impairs autoregulation of transmitter release in brain regions involved in spatial working memory formation such as the hippocampus. Indeed, mGluR7 has been implicated in a form of long-term depression (LTD) that can be elicited in stratum radiatum interneurons with stimulation of CA3 excitatory inputs (Laezza et al. 1999), and the pharmacological activation and internalization of this receptor has been shown to provide a metaplastic switch in CA3 stratum lucidum interneurons, which replaces mossy fiber-mediated LTD by long-term potentiation (Pelkey et al., 2005). Because mGluR7-induced LTD in CA3 interneurons requires PKC activation, PICK1 must be involved. All of these data are consistent with mGluR7 controlling synaptic plasticity, and thereby working memory, in the hippocampus via interaction with PICK1.

Because mGluR7a protein levels were reduced by $35-40 \%$ in homozygous $m G l u R 7 a^{A A A / A A A}$ mice, the increased susceptibility to PTZ and the short-term memory deficits seen in these animals could be attributable to insufficient receptor expression rather than impairment of PDZ-ligand interactions. However, heterozygous $m G l u R 7^{+/-}$mice show an even higher reduction in mGluR7 protein levels (50\%) but do not display increased susceptibility for PTZ-induced seizures (Sansig et al., 2001). We therefore conclude that the phenotype of the $m G l u R 7 a^{A A A / A A A}$ mice is not attributable to a reduction of mGluR7a gene expression but indeed the consequence of impaired protein interaction. The specific reasons for the reduced mGluR7a ${ }^{\text {AAA }}$ expression found in our knock-in animals are not known but may include increased rates of turnover and/or degradation of the mGluR7a protein in the absence of stabilizing PDZ interactions.

In summary, substitution of only the PDZ-ligand motif in mGluR7a suffices to cause functional deficits in synaptic signaling and a robust phenotype with increased PTZ-susceptibility and working memory deficits. Most likely, the strongly reduced interaction of PICK1 with the mutated mGluR7aAAA protein, and not the modest reduction in receptor protein levels detected in the $m G l u R 7 a^{A A A / A A A}$ mice, is responsible for these deficits. Also, we found no indication that increased synthesis of mGluR4 compensates for the dysfunctional mGluR7a ${ }^{\text {AAA }}$ protein. Similar to mGluR7a, the minor variant mGluR7b has a PDZ-ligand motif that binds PICK1 (El Far et al., 2000; Enz and Croci, 2003); the exon encoding the $\mathrm{C}$ terminus of mGluR7b has not been modified in our mutant mice. Hence, we conclude that important roles assigned to mGluR7a are not compensated by mGluR7b when mGluR7a is mutated. Inversely, the full behavioral phenotype of the $m G l u R 7^{-1-}$ mice is not recapitulated in the $m G l u R 7 a^{A A A / A A A}$ animals, suggesting that specific functions, such as the regulation of anxiety responses (Cryan et al., 2003; Mitsukawa et al., 2006), are independent of the PDZ-ligand motif of mGluR7a but might be mediated by mGluR7b. Our results imply that interaction with PDZ-proteins like PICK1 is necessary for mGluR7a function in vivo. Most likely, PICK1 is required for the recruitment of $\mathrm{PKC}$ to the mGluR7a signaling complex. In addition, it might be implicated in the regulation of other protein interactions and modifications occurring at the cytoplasmic tail of this presynaptic receptor. Clearly, additional studies will be required to resolve these questions.

\section{References}

Bach ME, Hawkins RD, Osman M, Kandel ER, Mayford M (1995) Impairment of spatial but not contextual memory in CaMKII mutant mice with a selective loss of hippocampal LTP in the range of the theta frequency. Cell 81:905-915.
Bertaso F, Lill Y, Airas JM, Espeut J, Blahos J, Bockaert J, Fagni L, Betz H, El-Far O (2006) MacMARCKS interacts with the metabotropic glutamate receptor type 7 and modulates $G$ protein-mediated constitutive inhibition of calcium channels. J Neurochem 99:288-298.

Boudin H, Craig AM (2001) Molecular determinants for PICK1 synaptic aggregation and mGluR7a receptor coclustering: role of the PDZ, coiledcoil, and acidic domains. J Biol Chem 276:30270-30276.

Boudin H, Doan A, Xia J, Shigemoto R, Huganir RL, Worley P, Craig AM (2000) Presynaptic clustering of mGluR7a requires the PICK1 PDZ domain binding site. Neuron 28:485-497.

Bradley SR, Levey AI, Hersch SM, Conn PJ (1996) Immunocytochemical localization of group III metabotropic glutamate receptors in the hippocampus with subtype-specific antibodies. J Neurosci 16:2044-2056.

Brandstätter JH, Koulen P, Kuhn R, van der Putten H, Wässle H (1996) Compartmental localization of a metabotropic glutamate receptor (mGluR7): two different active sites at a retinal synapse. J Neurosci 16:4749-4756.

Bushell TJ, Jane DE, Tse HW, Watkins JC, Garthwaite J, Collingridge GL (1996) Pharmacological antagonism of the actions of group II and III mGluR agonists in the lateral perforant path of rat hippocampal slices. Br J Pharmacol 117:1457-1462.

Callaerts-Vegh Z, Beckers T, Ball SM, Baeyens F, Callaerts PF, Cryan JF, Molnar E, D'Hooge R (2006) Concomitant deficits in working memory and fear extinction are functionally dissociated from reduced anxiety in metabotropic glutamate receptor 7-deficient mice. J Neurosci 26:6573-6582.

Cotman CW, Flatman JA, Ganong AH, Perkins MN (1986) Effects of excitatory amino acid antagonists on evoked and spontaneous excitatory potentials in guinea-pig hippocampus. J Physiol 378:403-415.

Cryan JF, Kelly PH, Neijt HC, Sansig G, Flor PJ, van Der Putten H (2003) Antidepressant and anxiolytic-like effects in mice lacking the group III metabotropic glutamate receptor mGluR7. Eur J Neurosci 17:2409-2417.

Dascal N, Lotan I, Gillo B, Lester HA, Lass Y (1985) Acetylcholine and phorbol esters inhibit potassium currents evoked by adenosine and cAMP in Xenopus oocytes. Proc Natl Acad Sci U S A 82:6001-6005.

Dev KK (2004) Making protein interactions druggable: targeting PDZ domains. Nat Rev Drug Discov 3:1047-1056.

Dev KK, Nakajima Y, Kitano J, Braithwaite SP, Henley JM, Nakanishi S (2000) PICK1 interacts with and regulates PKC phosphorylation of mGLUR7. J Neurosci 20:7252-7257.

El Far O, Betz H (2002) G-protein-coupled receptors for neurotransmitter amino acids: C-terminal tails, crowded signalosomes. Biochem J 365:329-336

El Far O, Airas J, Wischmeyer E, Nehring RB, Karschin A, Betz H (2000) Interaction of the $\mathrm{C}$-terminal tail region of the metabotropic glutamate receptor 7 with the protein kinase C substrate PICK1. Eur J Neurosci 12:4215-4221.

Enz R, Croci C (2003) Different binding motifs in metabotropic glutamate receptor type $7 \mathrm{~b}$ for filamin $\mathrm{A}$, protein phosphatase $\mathrm{C}$, protein interacting with protein kinase C (PICK) 1 and syntenin allow the formation of multimeric protein complexes. Biochem J 372:183-191.

Folbergrová J, Haugvicová R, Mares P (2003) Seizures induced by homocysteic acid in immature rats are prevented by group III metabotropic glutamate receptor agonist (R,S)-4-phosphonophenylglycine. Exp Neurol 180:46-54.

Fuhrmann JC, Kins S, Rostaing P, El Far O, Kirsch J, Sheng M, Triller A, Betz H, Kneussel M (2002) Gephyrin interacts with Dynein light chains 1 and 2, components of motor protein complexes. J Neurosci 22:5393-5402.

Gasparini F, Bruno V, Battaglia G, Lukic S, Leonhardt T, Inderbitzin W, Laurie D, Sommer B, Varney MA, Hess SD, Johnson EC, Kuhn R, Urwyler S, Sauer D, Portet C, Schmutz M, Nicoletti F, Flor PJ (1999) (R,S)-4phosphonophenylglycine, a potent and selective group III metabotropic glutamate receptor agonist, is anticonvulsive and neuroprotective in vivo. J Pharmacol Exp Ther 289:1678-1687.

Gereau RW 4th, Conn PJ (1995) Multiple presynaptic metabotropic glutamate receptors modulate excitatory and inhibitory synaptic transmission in hippocampal area CA1. J Neurosci 15:6879-6889.

Hirzel K, Müller U, Latal AT, Hulsmann S, Grudzinska J, Seeliger MW, Betz H, Laube B (2006) Hyperekplexia phenotype of glycine receptor alpha1 subunit mutant mice identifies $\mathrm{Zn}(2+)$ as an essential endogenous modulator of glycinergic neurotransmission. Neuron 52:679-690.

Hölscher C, Schmid S, Pilz PK, Sansig G, van der Putten H, Plappert CF 
(2004) Lack of the metabotropic glutamate receptor subtype 7 selectively impairs short-term working memory but not long-term memory. Behav Brain Res 154:473-481.

Hung AY, Sheng M (2002) PDZ domains: structural modules for protein complex assembly. J Biol Chem 277:5699-5702.

Kinoshita A, Shigemoto R, Ohishi H, van der Putten H, Mizuno N (1998) Immunohistochemical localization of metabotropic glutamate receptors, mGluR7a and mGluR7b, in the central nervous system of the adult rat and mouse: a light and electron microscopic study. J Comp Neurol 393:332-352.

Laezza F, Doherty JJ, Dingledine R (1999) Long-term depression in hippocampal interneurons: joint requirement for pre- and postsynaptic events. Science 285:1411-1414.

Laube B, Kuhse J, Rundstrom N, Kirsch J, Schmieden V, Betz H (1995) Modulation by zinc ions of native rat and recombinant human inhibitory glycine receptors. J Physiol 483:613-619.

Laube B, Hirai H, Sturgess M, Betz H, Kuhse J (1997) Molecular determinants of agonist discrimination by NMDA receptor subunits: analysis of the glutamate binding site on the NR2B subunit. Neuron 18:493-503.

Losonczy A, Somogyi P, Nusser Z (2003) Reduction of excitatory postsynaptic responses by persistently active metabotropic glutamate receptors in the hippocampus. J Neurophysiol 89:1910-1919.

Manahan-Vaughan D, Reymann KG (1995) Regional and developmental profile of modulation of hippocampal synaptic transmission and LTP by AP4-sensitive mGluRs in vivo. Neuropharmacology 34:991-1001.

Millan C, Luján R, Shigemoto R, Sánchez-Prieto J (2002) The inhibition of glutamate release by metabotropic glutamate receptor 7 affects both $[\mathrm{Ca} 2+] \mathrm{c}$ and cAMP: evidence for a strong reduction of Ca2+ entry in single nerve terminals. J Biol Chem 277:14092-14101.

Mitsukawa K, Mombereau C, Lötscher E, Uzunov DP, van der Putten H, Flor PJ, Cryan JF (2006) Metabotropic glutamate receptor subtype 7 ablation causes dysregulation of the HPA axis and increases hippocampal BDNF protein levels: implications for stress-related psychiatric disorders. Neuropsychopharmacology 31:1112-1122.

O'Connor V, El Far O, Bofill-Cardona E, Nanoff C, Freissmuth M, Karschin A, Airas JM, Betz H, Boehm S (1999) Calmodulin dependence of presynaptic metabotropic glutamate receptor signaling. Science 286:1180-1184.

Ohishi H, Nomura S, Ding YQ, Shigemoto R, Wada E, Kinoshita A, Li JL, Neki A, Nakanishi S, Mizuno N (1995) Presynaptic localization of a metabotropic glutamate receptor, mGluR7, in the primary afferent neurons: an immunohistochemical study in the rat. Neurosci Lett 202:85-88.
Okamoto N, Hori S, Akazawa C, Hayashi Y, Shigemoto R, Mizuno N, Nakanishi S (1994) Molecular characterization of a new metabotropic glutamate receptor mGluR7 coupled to inhibitory cyclic AMP signal transduction. J Biol Chem 269:1231-1236.

Pelkey KA, Lavezzari G, Racca C, Roche KW, McBain CJ (2005) MGluR7 is a metaplastic switch controlling bidirectional plasticity of feedforward inhibition. Neuron 46:89-102.

Perroy J, Prézeau L, De Waard M, Shigemoto R, Bockaert J, Fagni L (2000) Selective blockade of P/Q-type calcium channels by the metabotropic glutamate receptor type 7 involves a phospholipase $\mathrm{C}$ pathway in neurons. J Neurosci 20:7896-7904.

Perroy J, El Far O, Bertaso F, Pin JP, Betz H, Bockaert J, Fagni L (2002) PICK1 is required for the control of synaptic transmission by the metabotropic glutamate receptor 7. EMBO J 21:2990-2999.

Prézeau L, Carrette J, Helpap B, Curry K, Pin JP, Bockaert J (1994) Pharmacological characterization of metabotropic glutamate receptors in several types of brain cells in primary cultures. Mol Pharmacol 45:570-577.

Sansig G, Bushell TJ, Clarke VR, Rozov A, Burnashev N, Portet C, Gasparini F, Schmutz M, Klebs K, Shigemoto R, Flor PJ, Kuhn R, Knoepfel T, Schroeder M, Hampson DR, Collett VJ, Zhang C, Duvoisin RM, Collingridge GL, van Der Putten H (2001) Increased seizure susceptibility in mice lacking metabotropic glutamate receptor 7. J Neurosci 21:8734-8745.

Sassoè-Pognetto M, Wassle H, Grünert U (1994) Glycinergic synapses in the rod pathway of the rat retina: cone bipolar cells express the alpha 1 subunit of the glycine receptor. J Neurosci 14:5131-5146.

Scheschonka A, Tang Z, Betz H (2007) Sumoylation in neurons: nuclear and synaptic roles? Trends Neurosci 30:85-91.

Shigemoto R, Kulik A, Roberts JD, Ohishi H, Nusser Z, Kaneko T, Somogyi P (1996) Target-cell-specific concentration of a metabotropic glutamate receptor in the presynaptic active zone. Nature 381:523-525.

Tang Z, El Far O, Betz H, Scheschonka A (2005) Pias1 interaction and sumoylation of metabotropic glutamate receptor 8 . J Biol Chem 280:38153-38159.

Weiergräber M, Henry M, Krieger A, Kamp M, Radhakrishnan K, Hescheler J, Schneider T (2006) Altered seizure susceptibility in mice lacking the $\mathrm{Ca}(\mathrm{v}) 2.3$ E-type Ca2 + channel. Epilepsia 47:839-850.

Wischmeyer E, Döring F, Wischmeyer E, Spauschus A, Thomzig A, Veh R, Karschin A (1997) Subunit interactions in the assembly of neuronal Kir3.0 inwardly rectifying K+ channels. Mol Cell Neurosci 9:194-206.

Yang ZQ (2005) Agonists and antagonists for group III metabotropic glutamate receptors 6, 7 and 8. Curr Top Med Chem 5:913-918. 